\title{
French good practice guidelines for management of the risk of low back pain among workers exposed to manual material handling: Hierarchical strategy of risk assessment of work situations
}

\author{
Audrey Petit ${ }^{\mathrm{a}, \mathrm{b}, *}$, Philippe Mairiaux ${ }^{\mathrm{c}}$, Arnaud Desarmenien ${ }^{\mathrm{d}}$, Jean-Pierre Meyer $^{\mathrm{e}}$ \\ and Yves Roquelaure ${ }^{\mathrm{a}, \mathrm{b}}$ \\ ${ }^{a}$ Laboratory of Ergonomics and Epidemiology in Occupational Health, Faculty of Medicine of Angers, \\ LUNAM University, Angers, France \\ ${ }^{\mathrm{b}}$ Occupational Health Department, University Hospital of Angers, Angers, France \\ ${ }^{\mathrm{c} D e p a r t m e n t ~ o f ~ O c c u p a t i o n a l ~ M e d i c i n e ~ a n d ~ H e a l t h ~ E d u c a t i o n, ~ U n i v e r s i t y ~ o f ~ L i e ̀ g e, ~ L i e ̀ g e ~ B e l g i u m ~}$ \\ ${ }^{\mathrm{d}}$ Occupational Health Service ST72, Le Mans, France \\ ${ }^{\mathrm{e}}$ Department of Humans and Work, French National Institute for Research and Security, Vandoeuvre, France
}

Received 6 August 2014

Accepted 22 May 2015

\begin{abstract}
.
BACKGROUND: Manual material handling remains a major cause of occupational accidents and diseases in various sectors and occupations.

OBJECTIVE: This paper summarizes the main recommendations of the good practice guidelines of the French Society of Occupational Medicine for the risk assessment for back disorders in workers exposed to manual handling of loads.

METHODS: The guidelines were written by a multidisciplinary working group of 24 experts, according to the Clinical Practice Guidelines method proposed by French National Health Authority, and reviewed by a multidisciplinary peer review committee of 50 experts. Recommendations were based on a large systematic review of the international literature carried out from 1990 to March 2012 and classified (Grade A, B, C or expert consensus) according to their level of evidence.

RESULTS: The main recommendations are a three-level hierarchical method of risk assessment based on participatory ergonomics and suggested assessment tools that can be used routinely by professionals of occupational health, workers themselves and their supervisors.

CONCLUSION: These French guidelines are intended for professionals of occupational health in charge of the prevention of low back disorders. The recommended methods are applicable to other countries than France.
\end{abstract}

Keywords: Low back injury, hierarchical rating method, guidelines, lifting hazard

\section{Introduction}

*Address for correspondence: Audrey Petit, 4 Rue Larrey, 49933 Angers cedex 09, France. Tel.: +33 2413549 81; Fax: +33 2413534 48; E-mail: aupetit@chu-angers.fr.
Manual handling of loads is defined by the European legislation as "any transporting or supporting of a load, by one or more workers, including lifting, 
putting down, pushing, pulling, carrying or moving of a load, which, by reason of its characteristics or of unfavourable ergonomic conditions, involves a risk particularly of back injury to workers" (European Directive 90/269/EEC, art. 2). Manual material handling (MMH) involves a large number of workers in various sectors and occupations: Nearly a third of the European workers perform MMH for at least a quarter of their working time [1]. Half of male unskilled workers and one third of female unskilled workers are exposed to $\mathrm{MMH}$, according to a recent large French survey about monitoring of occupational risk exposures [2].

The most common disorders resulting from exposure to MMH are low back disorders that can lead to recurrent or chronic low back pain (LBP) and work disability [3-6]. MMH are also responsible for occupational injuries, limbs musculoskeletal disorders, cardiovascular and abdominal diseases. They are the main cause of occupational accidents (about a third) compensated by Social Insurance, and generate very high compensation costs in all industrialized countries $[5,7,8]$.

The ever changing work environment, with increasing work constraints, combined with ageing of the workforce, requires enhanced medical and occupational surveillance of workers exposed to $\mathrm{MMH}$. The French Society of Occupational Medicine has therefore developed good practice guidelines for the management of LBP in workers exposed to MMH, including risk assessment and prevention [9]. These guidelines are primarily intended for occupational physicians, occupational nurses and health and safety professionals. They are designed to define the appropriate workplace assessment needed in order to detect and prevent low back injuries. Among the various guidelines for the prevention of LBP at work previously published in the US and Europe [3, 5, 10-12] few have focused on recommendations concerning the risk assessment for back disorders related to $\mathrm{MMH}$.

The aims of this paper are therefore to summarise the main recommendations for the risk assessment for back disorders in workers exposed to manual handling of loads.

\section{Methods}

The guidelines were developed according to the Clinical Practice Guidelines method proposed by the French National Health Authority [13].

A systematic search of the literature was undertaken from January 1990 to March 2012 in several databases, websites, institutional reports and documentation of the main international institutions in charge of occupational health (Table 1).

On the basis of the data published in the literature and professional opinions, the proposed guidelines are classified as Grade A, B or C (Table 2). In the absence of studies, guidelines are based on a consensus between experts of the working party, after consulting the peer review group (Grade EC - Expert Consensus). The absence of grading does not mean that the guidelines are not relevant and useful, but indicates the need to conduct further studies.

Evidence linking was to the highest level of evidence and most recent source available i.e. previous guidelines or systematic review(s), which should include all of the earlier, original studies in that area. Direct reference to original studies was only made where there was no adequate review, when they were

Table 1

Strategy of literature search (according to the French National Health Authority, 2010 [11])

\begin{tabular}{llll}
\hline $\begin{array}{l}\text { Examined } \\
\text { databases }\end{array}$ & Search terms & $\begin{array}{l}\text { Found } \\
\text { references }\end{array}$ & Selected refrences \\
\hline - PubMed & "(manuals material handling OR & 2,800 titles and \\
- Embase & handling OR lifting OR carrying & abstracts & - 5 Guidelines \\
- Cochrane Library & OR pulling OR pushing OR & & -159 systematic \\
- NIOSHtic-2 & $\begin{array}{l}\text { physical work OR heavy work OR } \\
\text { manual workers) AND }\end{array}$ & -34 meta-analysis \\
& (observation OR posture OR & & - 279 clinical trials \\
& workload OR risk assessment OR & & \\
& task analysis OR occupational & & \\
& exposure OR job exposure OR & & \\
& ergonomic OR questionnaire OR & & \\
& biomechanical OR work-related & & \\
& OR measurement) AND (low back & & \\
& OR back OR musculoskeletal OR & & \\
& MSDs)" & & \\
\hline
\end{tabular}


Table 2

Recommendation grading (according to the French National Health Authority, 2010 [11])

\begin{tabular}{|c|c|}
\hline $\begin{array}{l}\text { Level of scientific proof provided by the literature } \\
\text { (for clinical studies) }\end{array}$ & Recommendation grading \\
\hline $\begin{array}{l}\text { Level } 1 \\
\text { - High-power randomised comparative studies } \\
\text { - Meta-analysis of randomised comparative studies } \\
\text { - Decision analysis based on well-conducted studies }\end{array}$ & $\begin{array}{c}\text { Grade A } \\
\text { Scientific proof established }\end{array}$ \\
\hline $\begin{array}{l}\text { Level } 2 \\
\text { - Low-power randomised comparative studies } \\
\text { - Well-conducted non-randomised comparative studies }\end{array}$ & $\begin{array}{c}\text { Grade B } \\
\text { Scientific proof presumed }\end{array}$ \\
\hline $\begin{array}{l}\text { Level } 3 \\
\text { - Case-control studies } \\
\quad \text { Level } 4 \\
\text { - Comparative studies with major bias } \\
\text { - Retrospective studies } \\
\text { - Case series }\end{array}$ & $\begin{array}{c}\text { Grade C } \\
\text { Low level of proof }\end{array}$ \\
\hline
\end{tabular}

not included in the review(s) or where they were necessary to support an important point. It is stressed that weak evidence statements on a particular relationship or effect do not necessarily mean that it is untrue or unimportant, but may simply reflect insufficient evidence or limitations of current scientific investigations.

The guidelines were written by a multidisciplinary working group of 24 experts and reviewed by a multidisciplinary peer review committee of 50 experts.

\section{Results}

The risk assessment of work situations is a major step in any preventive intervention to eliminate or reduce the risk of low back disorders, and therefore the guidelines state that "it is recommended that risk assessment results be used to select collective preventive measures at the company level". According to specific organization of occupational health prevention depending of country regulation, risk assessment should also be used "to define medical and occupational surveillance conducted at the individual level" (Grade EC).

A wide range of methods of risk assessment of $\mathrm{MMH}$ has been identified by recent systematic reviews, including self-reporting, observational methods and direct measurements [14-20]. However, the selection of an appropriate method or combination of methods that might be routinely used remains a challenge since the available literature does not allow to select one method in particular. The guidelines were therefore proposed on the basis of expert consensus "to assess exposure to MMH in the workplace by using (Grade EC):
- participatory ergonomics in order to promote a global approach to the work-related risks and preventive interventions;

- a stepwise strategy to assess the risks of low back disorders related to manual handling. For this purpose, the assessment should be based on a clear definition of the objectives and resources required for risk assessment, with stepwise combinations of risk assessment tools, and be regularly adjusted in response to changes in the company and job characteristics;

- a systemic approach to the job situation (including organizational and psychosocial characteristics) and risks (posture, vibration, etc.), due to the multiplicity of types of occupational exposures".

The guidelines recommend following "a threelevel stepwise evaluation defined as follows (Grade EC):

- First level: systematic detection at the company level of work situations associated with "problems" of low back disorders. To achieve this, it is recommended that (1) job characteristics are analysed in order to identify those work situations with confirmed (high level of LBP complaints) or potential (high levels of reported low back constraints) risks of low back disorders, (2) tools can be routinely applied by company personnel, including analysis of existing risk assessment documents (company dispensary logs, insurance records, workers' compensation records, accident reports, absentee records, etc.) and analysis of the difficulties (and complaints) reported by workers in performing some tasks. 
Table 3

Methods and assessment tools for low back risk related to MMH

\begin{tabular}{|c|c|c|c|}
\hline & \multicolumn{3}{|c|}{ Stepwise evaluation of risks related to $\mathrm{MMH}$} \\
\hline & STEP & METHODS & TOOLS \\
\hline \multirow[t]{3}{*}{ 1st level } & $\begin{array}{l}\text { Systematic detection of confirmed or } \\
\text { potential work situations at risk of } \\
\text { low back disorders }\end{array}$ & $\begin{array}{l}\text { Analysis of company health and } \\
\text { safety documents }\end{array}$ & $\begin{array}{l}\text { Company dispensary logs } \\
\text { Insurance and workers' } \\
\text { Compensation records } \\
\text { Accident reports } \\
\text { Absentee records }\end{array}$ \\
\hline & & $\begin{array}{l}\text { Global analysis of the difficulty of } \\
\text { performing certain tasks }\end{array}$ & $\begin{array}{l}\text { Feedback from workers and } \\
\text { supervisors reporting pain or } \\
\text { difficulties in performing certain } \\
\text { tasks }\end{array}$ \\
\hline & Risk identification & Observational methods & $\begin{array}{l}\text { Quick checklists } \\
\text { Checklist with scoring methods (1) } \\
\text { International standards (2) }\end{array}$ \\
\hline \multirow[t]{3}{*}{ 2nd level } & $\begin{array}{l}\text { Estimation of the risk level for the } \\
\text { work situations selected at level } 1\end{array}$ & Self-assessment methods & \\
\hline & & - physical workload & Borg scale (RPE, CR10) [26] \\
\hline & & - risk factors & $\begin{array}{l}\text { Visual Analogue Scale } \\
\text { Interviews } \\
\text { Questionnaires }\end{array}$ \\
\hline 3rd level & Analysis of complex situations & Detailed job analysis & $\begin{array}{l}\text { Ergonomic job analysis } \\
\text { Heart rate monitoring } \\
\text { NIOSH lifting equation [27] } \\
\text { Biomechanical modelling }\end{array}$ \\
\hline
\end{tabular}

(1) e.g., Manual Assessment Chart [22], FIFARIM checklist [23], etc. (2) AFNOR X 35-109 [24], CEN 1005-2, ISO 11228 [25].

- Second level: analysis of work situations considered to be potentially associated with high risk of low back disorder. To achieve this, it is recommended that (1) hazards are identified and the risk level of each work situation estimated, and (2) a risk assessment strategy is defined using readily available tools (Table 3 ), including self-reporting methods and tools (interviews, questionnaires, etc.), observational methods and tools (checklists, worksheets, etc.) and workload self-assessment tools (visual analogue scale, Borg's scale, etc.). Such analyses require the participation of workers and the technical expertise of the multidisciplinary occupational health team.

- Third level: in-depth analysis of complex situations. When the risk level cannot be determined based on the preceding steps, experts in ergonomics and in-depth analysis methods should be called upon (Table 3) to conduct a detailed analysis of the job characteristics and work situation".

Finally, the guidelines recommend that "the above risk assessment of work situations should be combined (when possible) with health surveillance data provided by medical examinations of exposed workers to estimate the risk level of low back disorders related to $\mathrm{MMH}$ " (Grade EC). However, "the risk assessment must not delay the search for preventive solutions when a high level of exposure to low back risk is obvious and must allow measurement of the efficacy of any preventive solutions implemented based on direct feedback from management and workers" (Grade EC).

\section{Discussion}

These recommendations are the first occupational guidelines for the management of work-related LBP in France. They have been elaborated according to the French system of occupational health, which includes OHS employing specialized occupational health physicians and nurses, but they are absolutely applicable to other countries as they are based on international methods and tools of $\mathrm{MMH}$ assessment. Although they are primarily intended for professional of occupational health and prevention - occupational physicians and specialized nurses, ergonomists, and safety engineers and practitioners - they are also intended for treating physicians (general practitioners, rheumatologists, rehabilitation physicians, orthopaedic surgeons, etc.) and paramedical personnel (physiotherapists, nurses, occupational therapists, psychologists) participating in the management of LBP. 
The recommendations are based on an extensive literature review and capitalize on recommendations of previous clinical practice guidelines related to the assessment and management of LBP at work $[3,5,11$, 12 ,]. However, in contrast to most guidelines focusing mainly on the clinical management of LBP and/or on their prevention in the workplace, these guidelines are among the first to include recommendations for a strategy of risk assessment for back disorders in workers exposed to MMH. The strategy and methods proposed might improve the understanding of the working activities of workers/patients by all practitioners involved in both the prevention of LBP in the workplace and the clinical management of LBP. Such methods and tools might increase the reliability of social representations of workers'/patients' work situations and ensure the consistency of prevention messages delivered by the numerous practitioners involved in the multidisciplinary management and prevention of LBP

Few guidelines and systematic reviews have been published concerning risk assessment methods for low back disorders in the workplace, in particular for manual material handlers, although many methods and tools have been presented in the literature. This is the reason why all recommendations were based on low grade evidence and expert consensus. However, the absence of grading did not mean that the guidelines were not relevant and useful, but indicated the need to conduct further studies.

The main recommendations of these guidelines are the hierarchical method of risk assessment based on participatory ergonomics and the suggested assessment tools that can be used routinely by professional of occupational health, workers themselves and their supervisors. The three-level strategy proposed is in line with the recommendations of the Belgian "SOBANE" strategy of occupational risk management [21]. The tools suggested have been selected based on their practicability and potentially wide diffusion in the occupational health community. No particular tools were selected in order to leave a range of options to be chosen by the users.

\section{Conclusion}

These guidelines can be used by all stakeholders involved in the prevention of occupational risks in order to advise companies on assessment of the risk of low back disorders and to implement prevention interventions. Their wide diffusion would improve the homogeneity of clinical practice in the management of LBP and promote a multidisciplinary approach of LBP prevention at the workplace.

\section{References}

[1] European Foundation for the Improvement of Living and Working Conditions - First findings from the fifth European Working Conditions Survey. European Union, Publication Office, 2010, EF/10/74/EN.

[2] DARES. L'évolution des risques professionnels dans le secteur priv 'e entre 1994 et 2010 : Premiers résultats de l'enquête SUMER (The development of occupational hazards in the private sector between 1994 and 2010: First results of the SUMER survey). DARES Analyses (Direction of the animation of research, studies and statistics) (in French). March 2012; ${ }^{\circ}$ 023:10.

[3] Burton AK, Balague F, Cardon G, Eriksen HR, Henrotin Y, Lahad A, et al. Chapter 2. European guidelines for prevention in low back pain: November 2004. Eur Spine J. 2006;15(Suppl 2):S136-68

[4] NIOSH. Ergonomic Guidelines for Manual Material Handling, National Institute for Occupational Safety and Health, 2007, DHHS (NIOSH) Publication No. 2007-131.

[5] Mairiaux P, Mazina D. Prise en charge de la lombalgie en médecine du travail. Recommandations de bonnes pratiques (The Belgium guidelines for management of low back pain in occupational health). Direction générale Humanisation du travail (The Belgium DG for Humanization of work) (in French). June 2008.

[6] Cole MH, Grimshaw PN. Low back pain and lifting: A review of epidemiology and aetiology. Work 2003;21(2): 173-84.

[7] CNAM-TS. Statistiques nationales des accidents du travail, des accidents de trajet et des maladies professionnelles (National statistics of occupational injuries, commuting accidents and occupational diseases). Caisse nationale d'assurance maladie des travailleurs salariés (National Health Insurance Fund for Employees) (in French), France. http://www.risquesprofessionnels.ameli.fr

[8] Robert Sauvé research institute in occupational health and safety (IRSST). Dossier Web "Manutention" (Handling web Report) (in French). IRSST (Quebec, Canada) www.irsst.

[9] Roquelaure Y, Petit A (coordinators). Surveillance médico-professionnelle du risque lombaire pour les travailleurs exposés à des manipulations de charges. Société Française de Médecine du Travail, octobre 2013, 296 p. (Medical and occupational surveillance of the low back risk in workers exposed to manual handling of loads). Société Française de Médecine du Travail et Haute Autorité de Santé (French Society of Occupational Medicine and French National Health Authority) (in French). Paris, France oct 2013. http://www.churouen.fr/sfmt/autres/Argumentaire_scientifique.pdf

[10] Carter JT, Birrell LN (Editors). Occupational health guidelines of low back pain at work. Faculty of Medicine, London, 2000.

[11] Waddell G, Burton AK. Occupational health guidelines for the management of low back pain at work: Evidence review. Occup Med (Lond) 2001;51(2):124-35.

[12] ACOEM. American College of Occupational and Environmental Medicine: Low back disorders. In: Hegmann KT, 
editor(s). Occupational medicine practice guidelines. Evaluation and management of common health problems and functional recovery in workers. 3rd ed. Elk Grove Village (IL): American College of Occupational and Environmental Medicine (ACOEM); 2011;333-796.

[13] Haute Autorité de santé (HAS): Elaboration de recommandations de bonne pratique. Recommandations pour la pratique clinique. Guide méthodologique (Elaboration of recommendations for good practice. Recommendations for clinical practice. Methodological Guide). Haute autorité de santé (French National Health Authority) (in French). SaintDenis la Plaine, France, 2010.

[14] David GC. Ergonomic methods for assessing exposure to risk factors for work-related musculoskeletal disorders. Occup Med 2005;55:190-199.

[15] Takala EP, Pehkonen I, Forsman M, Hansson GA, Mathiassen SE, Neumann WP, et al. Systematic evaluation of observational methods assessing biomechanical exposures at work. Scand J Work Environ Health 2010;36(1):3-24

[16] Malchaire J, Gauthy R, Piette A, Stramb F. Classification de méthode d'évaluation et/ou de prévention des risques de troubles musculosquelettiques (Evaluation method for classification and/or prevention of risks for musculoskeletal disorders). Département Conditions de travail, Santé et Sécurité, Institut syndical européen (ETUI) (Department of Working Conditions, Health and Safety, European Trade Union Institute) (in French). Belgium, 2011.

[17] Abedini R, Choobineh AR, Hasanzadeh J. Patient manual handling risk assessment among hospital nurses. Work. 2014 Jan 21.

[18] Karlheinz S, Max B, Michaela K, Ralph B. MultipLa-a tool for the combined overall estimation of various types of manual handling tasks. Work 2012;41(Suppl 1):4433-5.

[19] Steinberg U. New tools in Germany: Development and appliance of the first two KIM ("lifting, holding and carrying" and "pulling and pushing") and practical use of these methods. Work. 2012;41(Suppl 1):3990-6.

[20] Battevi N, Menoni O. Screening of risk from patient manual handling with MAPO method. Work. 2012;41(Suppl 1): 1920-7.
[21] Malchaire J et al. Stratégie SOBANE et guide de dépistage DEPARIS, série SOBANE (SOBANE and DEPARIS screening strategy guide, SOBANE series). Gestion des risques professionnels, Bruxelles, Service Public Fédéral Emploi, Travail et Concertation sociale (Occupational Risk Management, Federal Public Service of Employment, Labour, and Social Dialogue) (in French). Brussels, Belgium 2007.

[22] Health and Safety Executive. Manual Handling Assessment Charts. Sudbury, Suffolk, UK: HSE Books; 2003. http://www.hse.gov.uk/msd/mac

[23] Mairiaux P, Demaret J-Ph, Masset D, Vandoorne Ch. Manutentions manuelles. Guide pour Évaluer et prévenir les manutentions manuelles (Manual handling. Guide to assess and prevent manual handling). Service public fédéral Emploi, Travail et Concertation sociale, (Occupational Risk Management, Federal Public Service of Employment, Labour, and Social Dialogue) (in French). Brussels, Belgium, 2008:94.

[24] Association Française de Normalisation (AFNOR): Norme AF X 35-109. «Manutention manuelle de charge pour soulever, déplacer et pousser/tirer »- Méthodologie d'analyse et valeurs seuils (French Association for Standardization: Standard AF X 35-109. "Manual handling of load to lift, move and push / pull" - Analytical methodology and threshold values) (in French). AFNOR, La Plaine St-Denis, France, 2011.

[25] Association Française de Normalisation (AFNOR): Norme ISO 11228-2: Ergonomie - Manutention manuelle - Partie 2 : Actions de pousser et de tirer (French Association for Standardization: Standard ISO 11228-2: Ergonomics - manual handling - Part 2 : Actions of push and pull) (in French), AFNOR, La Plaine St-Denis, France, 2007.

[26] Borg G. Psychophysical scaling with applications in physical work and the perception of exertion. Scand J Work Environ Health 1990;16(suppl 1):55-8.

[27] Waters TR, Putz-Anderson V, Garg A, Fine LJ. Revised NIOSH equation for the design and evaluation of manual lifting tasks. Ergonomics 1993;36:749-76. 